\title{
The identification of the Indigenous population in Brazil's official statistics, with an emphasis on demographic censuses
}

\author{
Ricardo Ventura Santos ${ }^{\mathrm{a}, \mathrm{b}, *}$, Bruno Nogueira Guimarães ${ }^{\mathrm{a}}$, Alessandra Traldi Simoni ${ }^{\mathrm{c}}$, \\ Leandro Okamoto da Silvad ${ }^{\mathrm{d}}$, Marta de Oliveira Antunes ${ }^{\mathrm{d}}$, Fernando de Souza Damasco ${ }^{\mathrm{d}}$, \\ Rosa Sebastiana Colman ${ }^{\mathrm{e}}$ and Marta Maria do Amaral Azevedo ${ }^{\mathrm{c}}$ \\ ${ }^{a}$ Escola Nacional de Saúde Pública, Fundação Oswaldo Cruz, Rio de Janeiro, Brazil \\ ${ }^{\mathrm{b}}$ Departamento de Antropologia, Museu Nacional, Universidade Federal do Rio de Janeiro, Rio de Janeiro, Brazil \\ "Núcleo de Estudos de População "Elza Berquó”, Universidade Estadual de Campinas, Campinas, São Paulo, \\ Brazil \\ ${ }^{\mathrm{d}}$ Instituto Brasileiro de Geografia e Estatística, Rio de Janeiro, Brazil \\ ${ }^{\mathrm{e}}$ Faculdade Intercultural Indígena da Universidade Federal da Grande Dourados, Dourados, Mato Grosso do Sul, \\ Brazil
}

\begin{abstract}
This paper describes and contextualizes how the Indigenous population has been identified in Brazil's official statistics. In the complex trajectory of relations between Indigenous and non-Indigenous peoples in Brazil, which spans more than 500 years, the interests, perspectives and approaches adopted by initiatives seeking to identify the Indigenous population for the purposes of official statistics have assumed a variety of forms. At present, the diverse official sources contain a multitude of criteria for identifying Indigenous peoples.
\end{abstract}

Keywords: Indigenous peoples, identification, national censuses, Brazil

\section{Introduction}

Over the course of the history of colonization by Europeans, beginning in the sixteenth century, the Indigenous population inhabiting what is today the geographic area of Brazil - one of the largest countries in the world in territorial terms - experienced a huge demographic reduction due to epidemics, slavery, and countless other episodes of violence [1]. Even with all the difficulties involved in producing demographic estimates of the past given the absence of reliable data, the archaeological and historical evidence suggests that, at the time of the arrival of European col-

${ }^{*}$ Corresponding author: Ricardo Ventura Santos, Escola Nacional de Saúde Pública, Fundação Oswaldo Cruz, Rio de Janeiro, Brazil. E-mail: santos@ensp.fiocruz.br. onizers in 1500 , the Indigenous population was in the order of several million individuals, belonging to thousands of different societies [2]. The most recent statistics report that the Indigenous population in Brazil totals approximately 900,000 people, as reflected in the last national census, conducted in 2010 [3], which corresponds to less than $0.5 \%$ of the total Brazilian population.

In this complex trajectory of relations between Indigenous and non-Indigenous peoples in Brazil, the interests, perspectives and approaches adopted by initiatives seeking to identify the Indigenous population for the purposes of official statistics have assumed a variety of forms. If we take as a benchmark the national censuses, the first of which was conducted in 1872, we can discern a multitude of different perspectives concerning Indigenous peoples. In a text with the suggestive title of "Entering and leaving the 'melting pot': a 
history of Brazilian Indians in the national censuses," anthropologist João Pacheco de Oliveira argues that the censuses encapsulate the complexity of the "identification" processes relating to Indigenous populations in Brazil's official statistics: "A census unites many actors and resources, has its own agenda, and operates within a part of society that has its own interests and representations. The questions and methods of investigation that are used in a census are dictated by the problem of the construction of the Brazilian nation" [4, p. 193].

Setting out from a perspective informed by a combination of history, anthropology and demography, the goal of this paper is to describe and contextualize how the Indigenous population has been identified in Brazil's official statistics. Since the topic is wideranging and complex, we have opted to begin with a historical description concerning the relations between Indigenous peoples and colonization processes. Next, we take up the question of national demographic censuses as the main focal point of the analysis, given that presently they constitute the main sources of demographic data on the Indigenous population living in the country. In the final part of the text we explore some of the main challenges to the identification of Indigenous peoples in official statistics, discuss their implications and assess future prospects.

\section{Relations between the Brazilian State and Indigenous peoples}

Unlike the rest of Latin America, Brazil was colonized by Portugal in a process begun on the $21^{\text {st }}$ April 1500 with the arrival of Portuguese caravels on the Brazilian northeast coast. Brazil's colonial history spanned from nearly three centuries, with the country's independence from Portugal being proclaimed in 1822 , when it ceased to be a colony to become the Empire of Brazil, yet commanded by a heir to the Portuguese Court. In 1889, Brazil was declared a Republic. Brazil's administration, whether as a colony or as an independent country, worked to create mechanisms for administrating the Indigenous population, placing their lands, bodies and even identities in the service of the conquista enterprise [5-7].

In the 1910s, already in Brazil's Republican period, the first governmental agency specifically aimed at Indigenous populations was created, known as "Serviço de Proteção aos Índios" (SPI, or "Indigenous Protection Service"). It became the hub of indigenist policy in the first half of the twentieth century. SPI mission was to "emancipate" the Indigenous population, considered as "relatively incapable," in order to become workers able to contribute to Brazil's development $[6,8]$. The positivist idea that native peoples were closer to the "childhood of humanity," leaving their "older brothers" responsible for supervising their intellectual and cultural maturation [9], led to the Indigenous population being classified as without "legal competence" [10]. The notion of "tutela" (legal guardianship) was central to Brazilian governmental policies aimed at Indigenous populations during most of the $20^{\text {th }}$ century.

In the period from 1964 to 1985, reflecting the Cold War context, Brazil's government was controlled by the military (a period referred to as the "Military Dictatorship") when particular use was made of the legal notion of guardianship, employing it to curb the circulation of Indigenous leaders or threatening to "emancipate" them for their public denunciations of the abuses suffered by their peoples [9]. The capacity to make political speeches and seek to fight for rights were taken as evidence of leaving the "childhood of humanity" behind and becoming assimilated with national society, which threatened indigenous leaders. If they were emancipated for failing to meet the "criteria of Indianness" [9], these leaders could be prevented from returning to the lands of their peoples, isolating them from the day-to-day life and political support of their communities, still under state guardianship. At that period, social movements and anthropologists were highly critical of this specific conception of "emancipation" which, in the context of the military dictatorship, implied a loss of rights, not a gain in autonomy [9].

A fatalistic view of the destiny of native peoples pervaded almost the entire twentieth century: disqualified from contact with "national society" and struck down by epidemics of infectious diseases, the depopulation of the majority of the Indigenous communities was deemed irreversible [11]. The supposed impossibility of Indigenous peoples existing as culturally differentiated groups justified the civilizing mission of the State, expressed in the indigenist legislation and exemplified by the Law 6.001 of 1973 (also known as the "Indian Statute"). This law classified Indigenous groups as either "isolated", "in the process of being integrated" or "integrated", with the State being responsible for "preserving their culture and integrating [the Indigenous population] harmoniously into the national community" [12]. The same remit was given to the "Fundação Nacional do Índio" (FUNAI, or "National Indian Foundation"), which replaced the SPI as the fed- 
eral agency for Indigenous affairs in 1967 and still exists today. Among other functions, FUNAI is obliged to "protect the spontaneous acculturation of the Indian, so that his socioeconomic evolution takes place shielded from brusque changes" [13] (see also [14,15]).

From the 1970s, still in the context of the Military Dictatorship, civil society organizations began to conduct demographic surveys of Indigenous populations, which aimed to prove their existence and therefore influence the process of ensuring their rights - their land rights in particular [16]. These surveys were vital to showing that, despite the extermination of diverse populations, not only were Indigenous peoples not on the brink of disappearing, their population was actually growing. This "demographic turnaround" became a central fact in the dispute over the demographic paradigm concerning Indigenous peoples and was instrumental in the fight against assimilationist policies and their justification by fatalism. Over the 1980s, social movements, religious institutions, Indigenous leaders and academic researchers - demographers and anthropologists especially - became heavily involved in the debates on the number of Indigenous people living in Brazil, their population dynamics, and how the State should review the relationship established with these peoples who, as we shall see, were much more numerous than imagined [16].

A very significant change in indigenist legislation occurred in 1988 with the promulgation of Brazil's new Federal Constitution, a landmark in the return to democracy after the end of the military regime in 1985. As in other countries in Latin America, the assimilationist perspective in relation to Indigenous peoples was dropped in favour of a multiculturalist approach [4,17-19], which recognizes that Indigenous peoples "have standing to sue to defend their rights and interests" [20], thus abandoning state guardianship.

\section{Indigenous Lands}

The current Brazilian legislation about Indigenous Lands (ILs) (also referred as Indigenous Reserves) presents several particularities compared to other countries in the world. The 1988 Brazilian Constitution determines that: "Lands traditionally occupied by Indians are those on which they live on a permanent basis, those used for their productive activities, those indispensable for the preservation of environmental resources necessary for their well-being and those necessary for their physical and cultural reproduction, ac- cording to their uses, customs and traditions" [20]. Although ILs are defined as being in the permanent possession of the Indigenous population concerned, with exclusive use of their natural resources, they remain the property of the Union. Because of that, permission to exploit water or mineral resources in Indigenous Lands depends on approval by Brazilian National Congress. Under the Constitution, the affected communities should be heard, but they do not take part in the decisions on the projects concerned.

The localization of Indigenous Lands (ILs) provides a diagnostic snapshot of the colonial relation between the Brazilian State and the Indigenous population (Fig. 1). Currently approximately $13 \%$ of the Brazilian territory corresponds to ILs officially recognized by the State, totalling 486 homologated ILs, with $98 \%$ of the meshwork of demarcated ILs located in Legal Amazonia. The 422 ILs in Legal Amazonia occupy $115,344,445$ hectares (ha), while the 293 ILs in the rest of the country occupy 2,058,590 ha. On average the ILs in Legal Amazonia are 39 times larger in size than those found in other parts of the country, a contrast illustrative of the inequalities encountered in the recognition of Indigenous rights. In the regions where colonization is older and many economic enterprises exist, such as the states of the Northeast, South and Southeast, many ILs correspond to small areas that encompass little more than the residences of the Indigenous population, failing to assure the basic conditions needed for their cultural reproduction or survival. Even in those locations with a low demographic density, economic interests (of agribusiness, mining, land invasion or logging) seek to oppose the native fight for the territory. These are "endemic conflicts", which have worsened in the current setting in which FUNAI and the country's environmental policy are being dismantled, a process observed over the last few years [21].

These issues become even more complex as we take into consideration Indigenous movements across national frontiers, as it occurs with the Guarani (on Brazil's borders with Paraguay, Bolivia and Argentina), the Yanomami (located in the region of Brazil's border with Venezuela), the Tikuna (on the frontier with Colombia and Peru), and other peoples whose territories or relational networks are not limited to the borders of any single nation state. Also, there are some Indigenous peoples living in voluntary isolation (or semiisolation), whose lands are coveted by different economic sectors. State's policies regarding these people changed in the last couple decades: instead of trying to reach the "non-contacted peoples" and bring them 


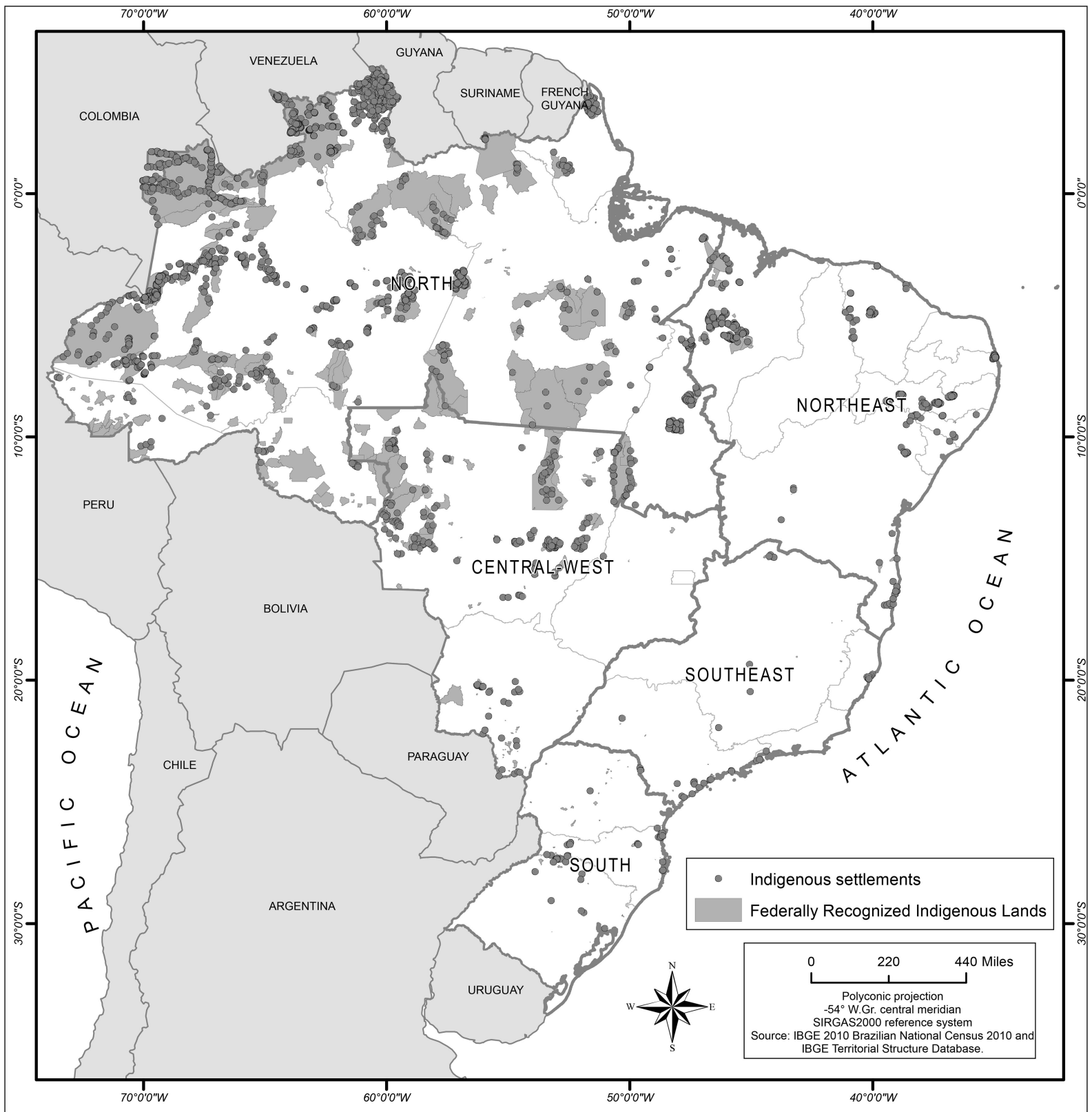

Fig. 1. Map showing current location of Federally Recognized Indigenous Lands (ILs).

close to the national society, the official policy shifted towards acknowledging them as in "voluntary isolation" and respecting their choice of non-interaction. The policy has been criticized by some politicians, who claim that defending "sanctuaries" for few and unknown Indigenous peoples will impact the country's economic development.

With the advances of the 1988 Federal Constitution and the recent loss of the legal guardianship of the State, Indigenous autonomy over their territory has increased but is far from sovereign. ${ }^{1}$ The economic

\footnotetext{
${ }^{1}$ In Brazil, some of the laws important to the definition of the State's relations with the Indigenous population are yet to be revised or updated, even after nearly three decades after the promulgation of the 1988 Federal Constitution. Such is the case of the "Indian Statute" [12], whose evolutionist principles (from "isolation" to "integration") continue at variance with the principle defended in the Federal Constitution: the "Indian Statute" remains officially valid despite its principles now being obsolete. With the absence of spe-
} 
forces with interests in exploiting the natural resources of the ILs are amply represented in Brazilian Federal Congress, making up the largest parliamentary caucus. Known by the abbreviation BBB (Beef, Bible and Bullets), they try to block the demarcation of new ILs through constitutional amendment projects. In recent years, the Federal Executive itself, responsible for demarcation, has been slow to recognize Indigenous territorial rights, especially in areas disputed with powerful economic oligarchies. Furthermore, in an era when Brazil's export economy is largely based on soybean cultivation and other primary commodities, representatives of agribusiness - strongly present in Congress - have delayed demarcations by launching various appeals against the State, imposing obstacles to the processes and simultaneously exhausting the resources of disputed lands through monocropping and enormous cattle herds [21].

Despite the advances made in terms of recognizing the rights of Indigenous peoples in Brazil in recent decades, the current perception is that various setbacks have occurred in the public policies for Indigenous populations in Brazil. This viewpoint has been repeatedly expressed by Indigenous leaders and by the sectors of academia and civil society that support Indigenous causes [21] and even by international agencies, as in the case of the United Nations (http://unsr. vtaulicorpuz.org/site/index.php/documents/countryreports/154-report-brazil-2016).

As well as the old question of land conflicts, new challenges emerged after the return to democracy. Indigenous peoples have also fought for public health and education policies to be suitably adapted to their sociocultural particularities. Until the 1990s, FUNAI concentrated the State functions relating to Indigenous peoples. With the changes to the structure of the State and the services provided after the military period, the Ministries of Health and Education assumed responsibility for the policies that fell under their area. As we shall see, this diversified the sources for the official data on Indigenous peoples, until then limited to indigenist bodies. Simultaneously, it implied that sectors of the State who had never dealt with Indigenous peoples began to develop specific policies for them. However, the difficulty of identifying who is Indigenous, especially those people living outside ILs, comprises a major issue in implementation of public policies. This is because FUNAI only operates in officially recognized

cific laws on Indigenous peoples after 1988, a vacuum persists in the legislation regulating the indigenist agency's operations [22].
ILs, providing no assistance to hundreds of thousands of Indigenous peoples outside them. Since the identification of the Indigenous population in urban centres in national-level demographic surveys has been associated with specific logistical problems, the statistical invisibility becomes an impediment to guaranteeing their rights.

\section{Sources of data on Indigenous peoples in Brazil}

As we saw earlier, the Brazilian State's relationship with Indigenous peoples was based, until 1988, on the conception that they eventually would no longer constituted ethnically differentiated social groups, whether due to physical extermination or to processes of assimilation. This perspective had direct impacts on the ways in which Indigenous peoples were identified and counted in official statistics over the twentieth century.

The decree instituting the SPI, issued in 1910, established that the agency should "carry out surveys of general statistics on the Indians, with a declaration of their origins, ages, languages and professions, and study their current situation, their habits and tendencies" [15]. The information had to be collected in a local and decentralized form at the Indigenous Posts run by the agency, where each head of post kept a register of births, marriages, and deaths [16]. In practice, although demographic data was routinely collected, at no moment during the SPI's existence (until 1967) were any continuous and systematic efforts made to consolidate, analyse or divulge this information with the aim of comprehending demographic trends.

Although the SPI failed to fulfil its mission of systemizing and divulging statistics on Indigenous peoples, it is worth pointing out that over the first half of the twentieth century a number of initiatives were undertaken by researchers that generated demographic profiles. These studies were produced independently in Brazilian universities and museums, but also among some government bodies, particularly the "Conselho Nacional de Proteção aos Índios" (CNPI, or "National Council for the Protection of Indians"), an entity connected to the SPI [23]. From this period, we can highlight the production of influential anthropologist Darcy Ribeiro who carried out extensive field research in numerous Indigenous communities.

Darcy Ribeiro (1922-1997) used information collected by the SPI heads of post to sketch for the first time a national demographic panorama of the Indigenous population [11]. This study was linked to the 
post-World War II "UNESCO Race Relations Project" research program, whose objective was to comprehend the situation of ethnic minorities in different countries in the context following the end of the Second World War (1937-1945) [24]. Ribeiro prioritized the analysis of the relation between Indigenous and nonIndigenous peoples, its impact on health and demography, and the action of the official indigenist body [25]. The presented data was later updated and projected in 1973 [26] as a form of accompanying and describing demographic trends. The conclusions presented in both publications were highly pessimistic when it comes to the future of Indigenous populations in Brazil, indicating not only the physical decline of these peoples, but also their "disintegration" as ethnic groups and their eventual assimilation into national society. This perspective was widespread among the anthropologists and indigenists of the period.

In 1967 the SPI was shut down and the FUNAI created in its place. The decree creating FUNAI, its functions similar in scope to the SPI, also stipulated that the new institutions should "carry out surveys, analyses, studies and scientific research on Indians, aiming to preserve their cultures and adapt the assistance programs to their needs" [13]. Thus, although the body had been created to change the way in which the State dealt with Indigenous peoples, few changes were made in order to improve the production of official data.

Another historical source of population data and information on Indigenous peoples in Brazil are the religious missions. Although the State had centralized the assistance provided to Indigenous peoples, Catholic and Protestant missionaries did not cease their activities, which included the production of monographs detailing aspects of the social life of these populations [27]. From 1970, influenced by Liberation Theology, some religious organizations began to review their work with Indigenous groups. This change had a significant impact on the future of Indigenous peoples in the Brazilian and wider Latin American settings [28], and the production of demographic data was central to this process. In that context, the "Conselho Indigenista Missionário" (CIMI, or "Indigenist Missionary Council") was the first organization to produce and publish data on the Indigenous population in Brazil. In 1982 the results of the national survey carried out by CIMI circulated nationally with the aim of informing the general public, missionaries and Indigenous peoples themselves about the Indigenous cause [29]. The data indicated the presence of Indigenous peoples in all five macro-regions of Brazil and pointed to the native population's growth, contradicting the official data and the perception dominant at the time.

Also at the end of the 1970s and throughout the 1980s, organizations working in support of Indigenous peoples in Brazil and the national Indigenous movement, which emerged during the same period, began to organize to demand recognition of Indigenous rights. As part of this movement, the "Centro Ecumênico de Documentação e Informação" (CEDI, or "Ecumenical Centre of Documentation and Information") launched the Indigenous Peoples in Brazil Program ("Programa Povos Indígenas no Brasil"), which, to a large extent supported by foreign funding, consolidated a broad network of collaborators. Participating in this network were researchers linked to the movements supporting Indigenous peoples, as well as indigenists, missionaries and Indigenous representatives. The publications containing the results of these initiatives also verified the widespread Indigenous presence in Brazil and its population growth [30], summarized in the phrase "the Indians are here to stay" [31]. In the early 1980s, debates about Indigenous demography and the need for official censuses started to take place at meetings of the "Associação Brasileira de Estudos de População" (ABEP - "Brazilian Association of Population Studies") $[32,33]$.

The combined evidences from various sources that Indigenous populations were experiencing a period of demographic growth were vital to advising the Constituent Assembly (1987/1988) at the end of the military dictatorship. In other words, it was the production of data by civil society, with the participation of Indigenous peoples, that provided the groundwork for a reversal in the State's logic of identifying, working with and producing information on Indigenous peoples in Brazil.

Following promulgation of the 1988 Constitution, there has been a proliferation of public policies aimed at Indigenous peoples in Brazil, which were based on new rights resulting from changes in legal status. The changes to the forms in which the State worked with Indigenous peoples were met with increased production of information related to demographic patterns, health, education, and social assistance by different government agencies and ministries [34,35] (Table 1). At present, the diverse official sources contain a multitude of criteria for identifying Indigenous peoples, not always mutually compatible. Current challenges include improving the collection and coverage of information, making the databases produced by the diverse institutions compatible, the divulgation of this data, as well as the appropriation of the latter by Indigenous peoples themselves. 


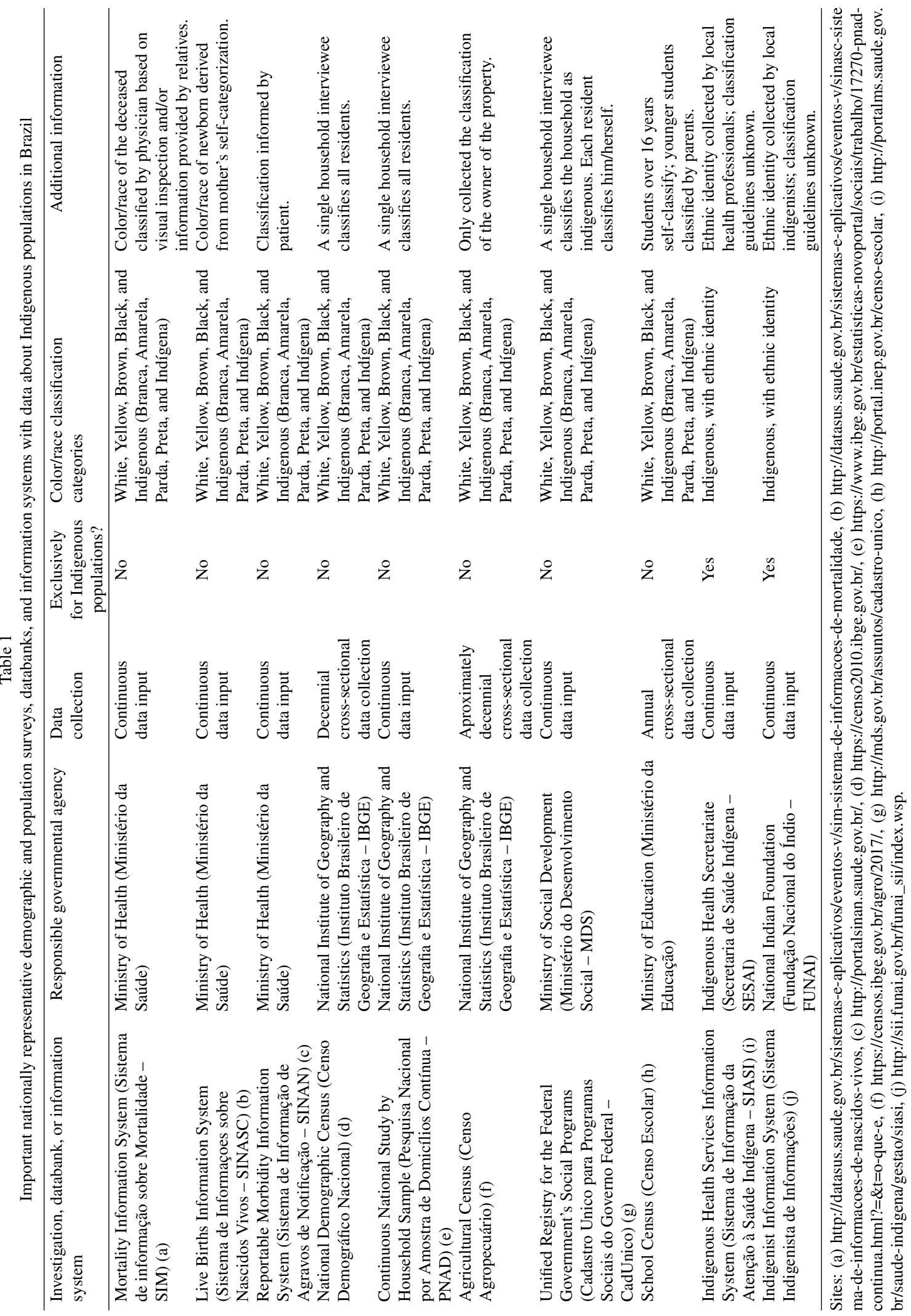


The 1988 Federal Constitution also changed the way in which the nation projected itself through the demographic census. The 1991 Census was the first to include the category Indigenous as a response option to the question 'What is your colour or race?'. Prior to that, the national Census, conducted since 1872, instructed enumerators to include the Indigenous population in a category of colour that represented some degree of "miscegenation," such as "pardo" (brown), "caboclo" or "mestiça" [36]. ${ }^{2}$ This change happened not only as an outcome of political debates within Brazil [40], but also due to international directives. In this setting, diverse Latin American countries included questions designed to gather data on Indigenous populations among the census rounds of 1980 and 2010 [41-43].

Between 1991 and 2000, the need was recognized to continue and improve the data collection on the Indigenous population in the national Demographic Censuses [44]. The advance in the identification and demarcation of Indigenous Lands by FUNAI, also allowed a greater refinement of the cartographic information on these areas, and consequently of the data gathered on this population [45].

The 2000 Demographic Census again included the Indigenous category in the question about colour/race, consolidating the Census as the largest source of information on Indigenous people, including giving visibility to the residents in urban areas. In 2005, based on census data, "Instituto Brasileiro de Geografia e Estatística" (IBGE, or "Brazilian Institute for Geography and Statistics") published for the first time a book outlining demographic trends and providing specific analyses of the population declaring itself Indigenous [46]. The 2000 data brought unexpected results that could not be explained by demographic dynamics alone, such as the large increase in Indigenous people in urban areas. This data, which we explore in the next section, pointed to the need and the analytic advantages of expanding the colour/race question to the universal questionnaire, answered by the Brazilian population as a whole, and also to the inclusion of the identification of ethnic belonging of individuals [46]. To meet these criteria, IBGE began to conduct studies to improve the

\footnotetext{
${ }^{2}$ Brazil is one of the few countries to continually classify its population in terms of colour/race in its censuses [37-39]. Out of the 12 demographic censuses taken, the question was not asked in only 3 occasions. Despite the invisibility of the "Indigenous" category over the course of history, in one way or another the censuses always expressed a concern in relation to the place of the Indigenous population in the national community.
}

methodology for gathering, compiling and distributing data on the Indigenous population [47]. These initiatives were undertaken in cooperation with government agencies through agreements with FUNAI, with institutes of official statistics in Latin America, following the international recommendations of the United $\mathrm{Na}-$ tional Declaration on the Rights of Indigenous Peoples, and with the academic community [45].

Through this endeavour, the 2010 Census introduced major innovations to the identification of the Indigenous population [48]. The question on colour/race was included in the universal questionnaire (in 1991 and 2000 they were part of the sample questionnaire) with the insertion of questions on ethnic group and language focused on those individuals declaring themselves Indigenous. The 2010 identification question was the following: "Your colour or race is", with the following options (in this order): "white", "black", "yellow", "brown", and "Indigenous". Those who declared "Indigenous" were additional asked: "What ethnic group or people do you belong to?" (open answer) and "Do you speak any Indigenous language at home?" ["yes" or "no" - if "yes", the respondent was asked "which language(s)?", listing up to two languages]. Also included was a cover question to the item on colour/race for households located in Indigenous Lands. In this case, if an individual did not declare him or herself Indigenous (in other words, self-identifying as "white," "black," "yellow," or "brown"), the person was asked "Do you consider yourself Indigenous?". In case of a positive answer, the questions about ethnic belonging and Indigenous languages were also made [48]. Thus the 2010 Census recorded as Indigenous people in Brazil the sum of all those who declared themselves "Indigenous" $(817,900)$ and all those who "considered themselves" Indigenous $(78,954)$, making a total of 896,900 Indigenous people in 2010.

In 2010, the innovations in the use of the PDA (an electronic questionnaire) and more precise georeferenced information, with a digitalized territorial base compatibilized with the borders of the ILs, enabled the application of questions concerning the specificity of these areas [45]. Hence, the georeferencing of the questionnaire allowed it to be better adapted to sociocultural particularities, including questions concerning sanitation and residences [45]. The census questions were asked in Portuguese and only eventually translated to Indigenous languages if native interpreters were available and requested by community leaders.

The 2010 Demographic Census met various international recommendations, such as self-identification, 
Table 2

Population size of Indigenous and non-Indigenous in urban and rural areas, according to the 1991, 2000, and 2010 Brazilian National Censuses

\begin{tabular}{|c|c|c|c|c|c|c|c|c|c|}
\hline & \multicolumn{3}{|c|}{ Urban } & \multicolumn{3}{|c|}{ Rural } & \multicolumn{3}{|c|}{ Total } \\
\hline & 1991 & 2000 & 2010 & 1991 & 2000 & 2010 & 1991 & 2000 & 2010 \\
\hline Indigenous & 71,026 & 383,298 & 315,192 & 223,105 & 350,829 & 502,783 & 294,131 & 734,127 & 817,963 \\
\hline Non-Indigenous & $110,494,732$ & $137,003,552$ & $180,605,298$ & $35,492,049$ & $31,662,628$ & $29,325,929$ & $145,986,780$ & $168,666,180$ & $189,931,228$ \\
\hline$\%$ Indigenous & 0.06 & 0.28 & 0.17 & 0.62 & 1.10 & 1.69 & 0.20 & 0.43 & 0.43 \\
\hline
\end{tabular}

Source: IBGE (2012).

the diversity of ethnic identification criteria, which included the language spoken, the ethnic group or people to which the person declaring him or herself Indigenous belongs, and questions with options adjusted to the Indigenous people living in Indigenous Lands (in particular relating to sanitation) and the employment of Indigenous interpreters when requested by community leaders [48].

\section{What does the demographic census data tell us about the Indigenous population in Brazil?}

As indicated previously, the National Demographic Censuses conducted by IBGE currently constitute the main sources of demographic data on Indigenous populations in Brazil. ${ }^{3}$ In this section we begin by describing the general characteristics concerning the Indigenous population in the 1991, 2000 and 2010 Censuses (with an emphasis on the size of the population and its distribution according to regions of the country in the urban and rural sectors). ${ }^{4}$ Next, we present some of the results derived from the 2010 Census, including variables introduced only in the most recent census, such as classification of Indigenous ethnic group and whether the person spoke an Indigenous language at home. Finally, we briefly examine the differences

\footnotetext{
${ }^{3}$ Contemporary National Demographic Censuses undertaken in Brazil are planned to count all the residents in the country, including institutionalized populations (e.g. the incarcerated and those living in nursing homes). A notable exception is that the National Census does not aim to count Indigenous populations considered by FUNAI to be "in isolation," defined as those living "without permanent relations with national societies or with infrequent interactions with nonIndigenous or other Indigenous peoples" (see http://www.funai.gov. br/index.php/nossas-acoes/povos-indigenas-isolados-e-de-recentecontato, accessed December 7, 2018).

${ }^{4}$ Since 2000 , IBGE has published detailed overviews of the census results about Indigenous population $[3,46]$ and also made available part of the census microdata for public access, which might be downloaded from the institutional website. It is also possible to generate pre-formatted outputs using online cross-tabulation information systems, including SIDRA (http://www.ibge.sidra.gov.br) and BME (http://www.bme.gov.br).
}

between the Indigenous and non-Indigenous population in terms of literacy ${ }^{5}$ and income, as well as indicators relating to fertility and mortality. It is important to stress that in all the analyses we used exclusively the information from the question on colour or race, not including therefore those individuals who "considered themselves" Indigenous in 2010, as discussed in the previous section.

Table 2 compares the sizes in urban and rural areas of Indigenous and non-Indigenous populations in the 1991, 2000 and 2010 Censuses. It is notable that over the period of two decades, the Indigenous population varied from 294,131 in 1991 to 817,963 in 2010 , or in other words it almost tripled. This was the biggest increase among all the categories of colour/race routinely collected by the censuses in Brazil (namely white, black, yellow, brown, undeclared results). For the nonIndigenous population, the relative variation in growth was much less expressive, rising from 146 to 189 million people between 1991 and 2010, not even doubling therefore.

In the case of Indigenous people living in urban areas, the census data indicate substantial growth between 1991 and 2000, followed by a drop between 2000 and 2010 (Table 2). In the rural area, the trend was growth over the course of three censuses. For nonIndigenous people, while the population in urban areas grew from 1991 to 2010, in the rural area a reduction was observable.

Despite the variation in the size of the Indigenous population between censuses, one constant is the low proportion in relation to the Brazilian population in general (Table 2). Considering the urban and rural areas combined, $0.43 \%$ of the Brazilian population was Indigenous in 2010, a figure similar to 2000 and slightly higher than 1991. In the rural area, there was an upward trend in the proportion of Indigenous people compared to the total population of the country, rising from $0.62 \%$ in 1991 to $1.69 \%$ in 2010 .

\footnotetext{
${ }^{5}$ The definition of "literacy" used by IBGE is the following: "person 5 years of age or more able to read and write a simple note in the language he or she knows" [46].
} 
In the discussions on the demography of the Indigenous population in Brazil, one of the most debated questions concerning the census data is related to the variation observed in urban areas between 1991 and 2000 , when there was a jump from 71,026 to 383,298 persons, which was translated into the previously cited growth of $+20.8 \%$ per year (Table 2 ). Discarding the improbable and already cited explanation of a mass rural-urban migration of Indigenous people in the period, what may have occurred was an increase in people opting to declare themselves as Indigenous to the census takers in 2000.

Among the various contextual elements highlighted to explain this variation is the observation that data collection for the 2000 Census took place in the heat of the debates related to the $500^{\text {th }}$ anniversary of the arrival (commonly referred to as "invasion") of Europeans in Brazil (see Section 2). In this scenario, a valorisation of Indigenous identity may have occurred, subsequently reflected in the data collected for the demographic census [44,49-54]. In April 2000, a few months prior to the 2000 Census research starting, in July 2000, several manifestations took place in various regions of the country, some of which led to confrontations of Indigenous leaders and supporters with the police. These were widely publicized in the media [55]. Recognized as ethnic minorities, vulnerable and confronting powerful interests in order to guarantee their rights, principally access to their land, the historical and sociopolitical context of 2000 may have stimulated people to selfidentify as Indigenous in the national census. The fact that in 2000 there was a higher proportion of Indigenous people in urban areas compared to rural strongly suggests a different pattern at work in this specific census (Table 2).

Beyond demographic factors, therefore, the quantitative variations observed in the Indigenous population in Brazil in the different demographic censuses may be associated with methodological differences between the censuses (such as the inclusion of questions on belonging to Indigenous ethnic groups and Indigenous languages in 2010) and the processes of ethnic-racial reclassification related to specific historical and sociopolitical contexts. Analyses of the variations of the Indigenous population in diverse countries also point to the importance of identity factors [56]. In the Brazilian case, studies analysing the variation in the Indigenous population (see revision in Bastos et al. [57]) highlight the fact that, in part, the differences observed may be due to "ethnogenesis" - that is, processes of ethnic re-emergence of Indigenous peoples.
Table 3

Urban-rural distribution (\%) of the Indigenous and non-Indigenous population by geographical regions, according to the 2010 Brazilian National Census

\begin{tabular}{lccc}
\hline & Urban & Rural & Total \\
\hline Indigenous & & & \\
$\quad$ North & 19.5 & 48.6 & 37.4 \\
Northeast & 33.7 & 20.4 & 25.5 \\
Southeast & 25.1 & 3.7 & 12.0 \\
South & 10.8 & 8.1 & 9.2 \\
Central-west & 10.9 & 19.1 & 16.0 \\
Total & 315,192 & 502,771 & 817,963 \\
& $(100 \%)$ & $(100 \%)$ & $(100 \%)$ \\
Non-Indigenous & & & \\
North & 7.2 & 13.5 & 8.2 \\
Northeast & 24.1 & 48.3 & 27.8 \\
Southeast & 46.5 & 19.3 & 42.3 \\
South & 14.5 & 13.9 & 14.4 \\
Central-west & 7.8 & 5.0 & 7.3 \\
Total & $160,605,299$ & $29,325,929$ & $189,931,228$ \\
& $(100 \%)$ & $(100 \%)$ & $(100 \%)$ \\
\hline
\end{tabular}

Source: SIDRA/IBGE.

Owing to the violence of colonization, only in recent periods have Indigenous people from diverse groups, many of them with lengthy histories of interaction with non-Indigenous populations, begun to express their Indigenous ethnic belonging in the context of census investigations conducted by government agencies.

Taking the 2010 Census as a reference point, Table 3 presents the distribution of the Indigenous and nonIndigenous population according to the region of residence in Brazil. We can note a differentiated pattern with approximately half $(48.6 \%)$ of the rural Indigenous population living in the North region, while there was a predominance of Indigenous residents in urban areas in the Northeast (33.7\%) and Southeast (25.1\%). For non-Indigenous, nearly half of those who lived in urban and rural areas resided in the Southeast (46.5\%) and in the Northeast (48.3\%), respectively, which is a distribution pattern that greatly differs from that of the Indigenous population (Table 3 ).

This urban-rural pattern aligns with the distribution of Indigenous Lands in the Brazilian territory, the largest of which are located in the North region (Fig. 1). In 2010, 116,971 (37.1\%) of the 315,180 Indigenous people living in urban areas were resident in urban regions of metropolitan regions of the CentreWest, Northeast, Southeast and South (SIDRA IBGE's Automatic Data Recovery System, Table 3175). As for the Indigenous residents in rural areas, $85.9 \%$ lived in Indigenous Lands [1].

Although the Indigenous population in Brazil only corresponded to $0.43 \%$ of the total Brazilian population in 2010 (Table 2), some areas have a pronounced 
Indigenous presence [3]. In 2010, the country was divided into 5,564 municipalities and the Federal District. Approximately a quarter $(24.1 \%$ or 197,319 individuals) of the country's total Indigenous population resided in a group of just 20 of these municipalities. The majority of the latter, 11 in total, were located in the North region with the others located in the Centre-West (4 municipalities), Southeast (3) and Northeast (2). These municipalities with a larger absolute number of Indigenous residents presented two profiles: 14 of them had $20 \%$ or more of the population constituted by Indigenous people, generally small municipalities with less than 15,000 inhabitants; on the other hand, three municipalities (Salvador, Rio de Janeiro and São Paulo) form part of large metropolitan regions, as well as being capitals of their respective states. In these three municipalities resided thousands of Indigenous inhabitants (7,563, 6,764 and 12,997, respectively), but the proportions of Indigenous people compared to the total population were small $(<0.30 \%$ in the three cases, which is lower than the $0.43 \%$ for the country as a whole).

There were striking differences in the age composition of the Indigenous population living in urban and rural areas in Brazil in 2010 (Fig. 2). In the case of rural areas, roughly $50 \%$ of the Indigenous populations were aged 20 or under. For comparative purposes, the age structures for the non-Indigenous population are also shown in Fig. 2, demonstrating that the Indigenous residents of urban areas present an age distribution similar to that of the non-Indigenous population.

As indicated previously, there was a marked expansion in the data collection relating to the Indigenous population in the 2010 Census compared to earlier censuses in Brazil. There is, therefore, a large volume of information whose content cannot be covered in detail in the present text. Consequently, we have opted to list a set of findings that, in our view, are particularly significant when considering the question of the identification of Indigenous populations in Brazil through census data: (1) the respondents who classified themselves as Indigenous referred to a total of 305 Indigenous ethnic groups and 274 Indigenous languages spoken at home $[3$, p. 85, 90]; (2) the largest three Indigenous ethnic groups in population terms were the Tikúna $(46,045$ people), Guarani Kaiowá $(43,401)$ and Kaingang $(37,470)$ [3, p. 89]; (3) there was a predominance of groups containing a few hundred individuals, given that $22.7 \%$ were composed of $<100$ people; $29.2 \%$ between 100 and 499; 27.9\% between 500 and 1999; and only $20.1 \%$ over 2000; (4) while almost all the interviewees (99.9\%) in Indigenous Lands referred to a specific Indigenous ethnic group, outside the ILs the proportion was $61.4 \%$ [3, p. 86]; (5) generally speaking, in the urban areas of the various regions of the country in 2010, there was a predominance of people who classified themselves as Indigenous who did not cite affiliation to any specific Indigenous ethnic group. Considering the response "does not know ethnic group" for those who declared themselves Indigenous in the question on colour or race, the percentages were $2.2 \%$ in rural areas $(0.5 \%$ in the North; $5.7 \%$ in the Northeast; $8.5 \%$ in the Southeast; $4.0 \%$ in the South; $0.8 \%$ in the Centre-West) and $43.1 \%$ in urban areas (15.4\% in the North; $46.6 \%$ in the Northeast; $57.8 \%$ in the Southeast; $52.8 \%$ in the South; $38.7 \%$ in the Centre-West) (Source: BME/IBGE - "Banco Multidimensional de Estatísticas", or "Multidimensional Data Bank").

These findings point to a scenario of considerable ethnic and linguistic sociodiversity among the Indigenous population in Brazil, one of the most pronounced in Latin America, with a prevalence of societies with generally small population sizes (a few hundred people) and living predominantly in Indigenous Lands. ${ }^{6}$ In addition, the 2010 census data showed that, in terms of the Indigenous population residing in urban areas, a large number $(43.1 \%)$ consider themselves to be Indigenous-descendants but without reference to specific Indigenous groups.

As a nationwide demographic survey, the 2010 Census produced for the Brazilian population in general, including the Indigenous population, a vast range of sociodemographic data that still remains to be explored in detail. In terms of the Indigenous population, relatively little has been investigated concerning themes linked to education, work, income, residential conditions, fertility, mortality and migration, for example [3]. While recognizing that the national censuses present various limitations when it comes to gathering data on socioculturally differentiated populations, as is the case of Indigenous peoples in Brazil [53,59-61], in Tables 4 and 5 we present comparisons between these groups in relation to literacy rates in three age

\footnotetext{
${ }^{6}$ The other main source of information on the diversity of Indigenous peoples in Brazil is the NGO Instituto Socioambiental (ISA). ISA's data refers to peoples living in Indigenous Lands. In the most recent published compilation, ISA's survey indicated 252 Indigenous peoples and 715,213 individuals [58, p. 17]. Considering the heterogeneity of criteria used by the IBGE and ISA, we can note when comparing their data that the differences are not particularly pronounced.
} 

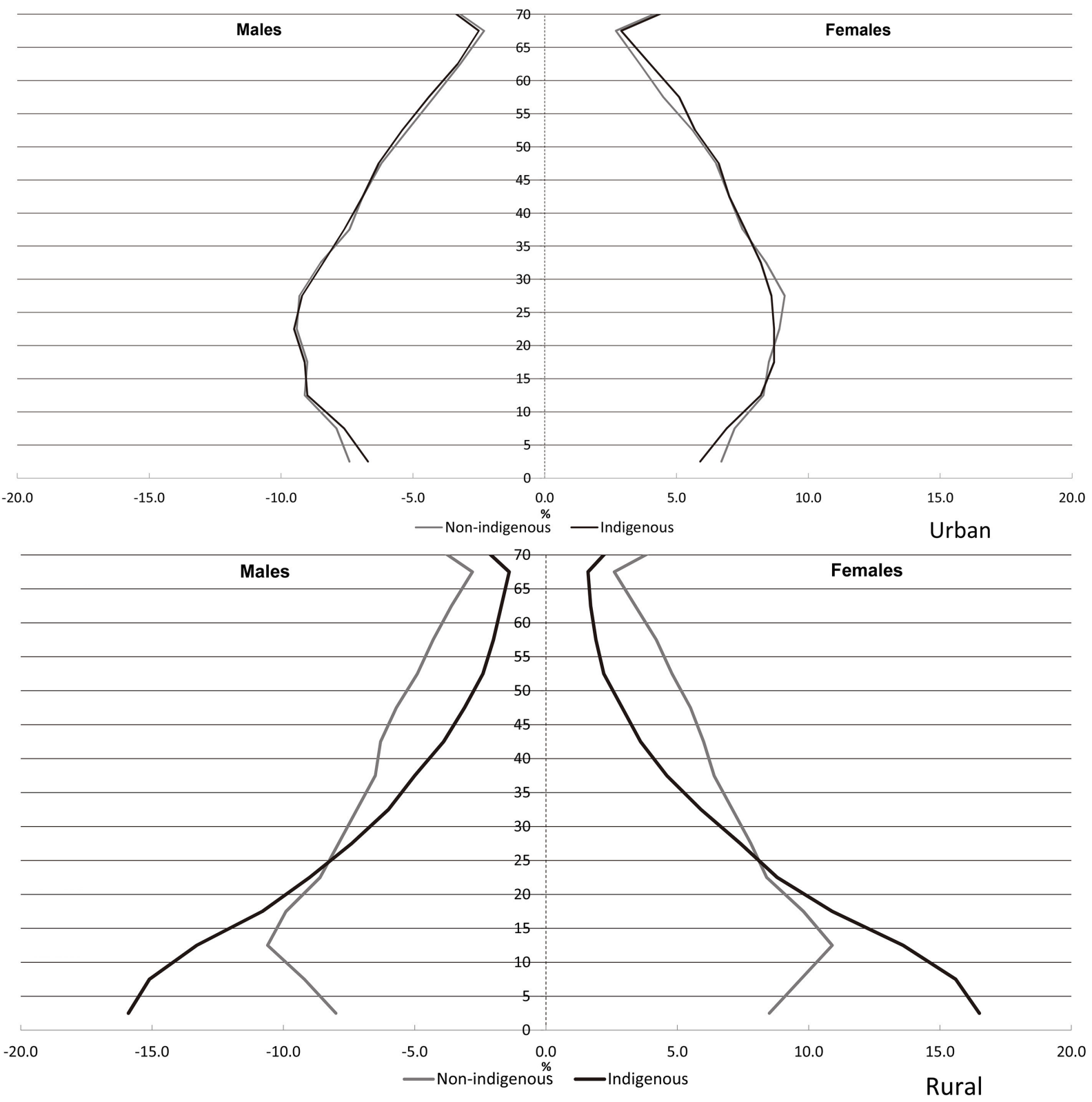

Fig. 2. Age distribution of indigenous and non-indigenous populations by gender and urban-rural residency, according to the 2010 Brazilian National Census.

groups (5 to $14.9,15$ to 19.9 , and 20 to 39.9 years) and income among young adults (20 to 39.9 years). These comparisons point to effective disadvantages for the Indigenous population in comparison to the nonIndigenous population in Brazil (Figs 3 and 4). This is a pattern expressed consistently in the various regions of the country, especially in rural areas. It should be pointed out that levels of literacy and income are nonIndigenous parameters that do not necessarily take into account or reflect Indigenous dynamics of learning and native economic modalities. Nonetheless, in context of inevitable interaction between Indigenous groups and the surrounding Brazilian society, especially for those without access to territory (as is the case of most of the residents of urban areas), differentials in literacy and income potentially translate into effective disadvantages in terms of socioeconomic opportunities compared to non-Indigenous inhabitants.

Until recently no estimates were available on the fertility rates of the Indigenous population in Brazil that 
Table 4

Frequency (\%) of literacy* in 5-14.9, 15-19.9, and 20-39.9 year-old Indigenous and non-Indigenous, by urban-rural residency and geographical regions, according to the 2010 Brazilian National Census

\begin{tabular}{|c|c|c|c|c|c|c|}
\hline & \multicolumn{2}{|c|}{ Rural } & \multicolumn{2}{|c|}{ Urban } & \multicolumn{2}{|c|}{ Total } \\
\hline & Indigenous & Non-Indigenous & Indigenous & Non-Indigenous & Indigenous & Non-Indigenous \\
\hline \multicolumn{7}{|l|}{$5-14.9$ years } \\
\hline North & 52.9 & 65.6 & 77.6 & 79.8 & 56.9 & 75.6 \\
\hline Northeast & 58.7 & 70.1 & 79.5 & 80.4 & 66.9 & 77.2 \\
\hline Southeast & 63.8 & 86.4 & 88.8 & 88.1 & 80.0 & 87.9 \\
\hline South & 81.2 & 88.4 & 85.3 & 88.2 & 82.3 & 88.3 \\
\hline Central-west & 70.1 & 84.2 & 85.8 & 86.9 & 72.4 & 86.6 \\
\hline Total & 60.2 & 74.8 & 81.8 & 85.2 & 65.8 & 83.3 \\
\hline \multicolumn{7}{|l|}{ 15-19.9 years } \\
\hline North & 75.7 & 93.9 & 96.4 & 98.1 & 80.0 & 97.0 \\
\hline Northeast & 88.9 & 93.7 & 96.7 & 96.8 & 92.5 & 95.9 \\
\hline Southeast & 88.4 & 98.2 & 98.7 & 98.9 & 96.0 & 98.9 \\
\hline South & 95.6 & 98.8 & 97.7 & 99.2 & 96.4 & 99.1 \\
\hline Central-west & 88.6 & 98.4 & 98.1 & 99.1 & 90.7 & 99.0 \\
\hline Total & 83.1 & 95.3 & 97.3 & 98.4 & 83.0 & 95.2 \\
\hline \multicolumn{7}{|l|}{ 20-39.9 years } \\
\hline North & 68.9 & 86.7 & 92.5 & 96.2 & 74.4 & 94.1 \\
\hline Northeast & 74.6 & 78.7 & 92.1 & 92.5 & 84.3 & 89.2 \\
\hline Southeast & 82.2 & 93.7 & 97.4 & 98.2 & 94.9 & 97.9 \\
\hline South & 85.6 & 96.6 & 95.6 & 98.6 & 90.5 & 98.3 \\
\hline Central-west & 80.2 & 93.8 & 95.8 & 97.8 & 85.3 & 97.4 \\
\hline Total & 74.2 & 85.8 & 94.3 & 96.7 & 87.9 & 97.8 \\
\hline
\end{tabular}

Source: BME/IBGE. * See note 5 for the definition of "literacy" used by IBGE.

Table 5

Frequency (\%) of 20-39.9 year-old Indigenous and non-Indigenous without income or income below one Brazilian minimum salary, by urbanrural residency and geographic regions, according to the 2010 Brazilian National Census

\begin{tabular}{|c|c|c|c|c|c|c|}
\hline & \multicolumn{2}{|c|}{ Rural } & \multicolumn{2}{|c|}{ Urban } & \multicolumn{2}{|c|}{ Total } \\
\hline & Indigenous & Non-Indigenous & Indigenous & Non-Indigenous & Indigenous & Non-Indigenous \\
\hline North & 94.2 & 86.7 & 75.6 & 65.2 & 89.9 & 70.0 \\
\hline Northeast & 93.7 & 93.0 & 75.8 & 74.7 & 83.8 & 79.1 \\
\hline Southeast & 80.4 & 73.5 & 47.3 & 45.3 & 52.6 & 47.1 \\
\hline South & 84.4 & 60.3 & 46.8 & 36.6 & 65.7 & 39.6 \\
\hline Central-west & 89.4 & 64.9 & 57.3 & 47.8 & 78.9 & 49.4 \\
\hline Total & 91.8 & 82.6 & 63.3 & 52.9 & 79.3 & 57.0 \\
\hline
\end{tabular}

Source: BME/IBGE.

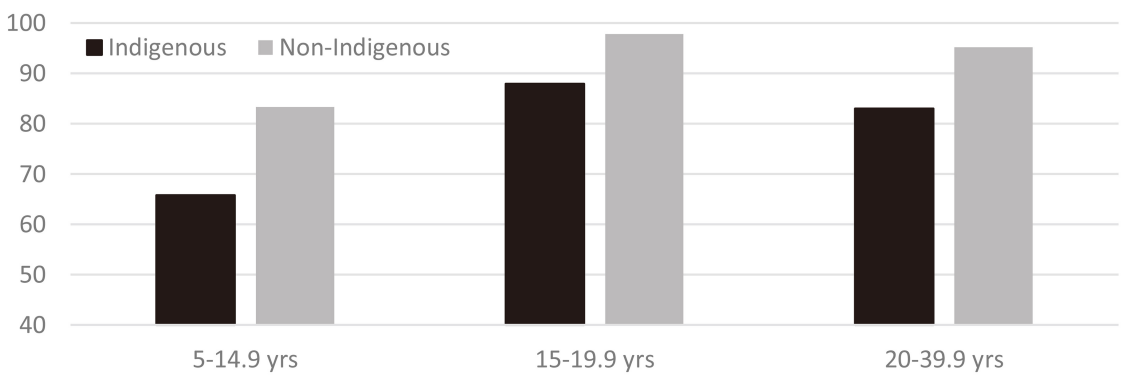

Fig. 3. Frequency (\%) of literacy in 5-14.9, 15-19.9, and 20-39.9 year-old Indigenous and non-Indigenous, according to the 2010 Brazilian National Census.

were representative for the country as a whole [16]. Following the inclusion of the Indigenous category in the 1991 Census, it became possible to generate fertility estimates for Indigenous women at national level and compare these with other sectors of the Brazilian population [62]. The analyses of the fertility of the Indigenous population based on census data from 1991, 2000 and 2010 indicate a downward trend in total fer- 


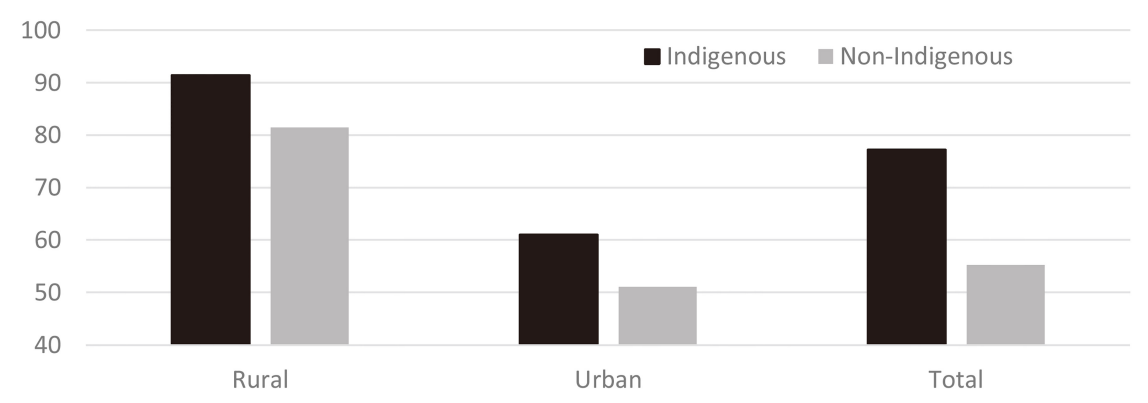

Fig. 4. Frequency (\%) of 20-39.9 year-old Indigenous and non-Indigenous without income or income below one Brazilian minimum salary, according to the 2010 Brazilian National Census.

tility rates (TFRs) ${ }^{7}(5.4,3.9$ and 3.8, respectively) [62]. The changes in the levels in rural areas across the three censuses $(6.7,6.1$ and 4.8$)$ proved to be significantly higher than for those in urban areas $(2.9,2.6$, and 2.8). The downward trend in fertility observed for the Indigenous population is especially linked, therefore, to women living in rural areas, with little variation shown for those residents in urban areas. These differentials are reflected in the age composition of the Indigenous population, which, as indicated earlier, is substantially younger in rural areas (Fig. 2). In comparative terms, the TFRs of Brazilian women in general in 2000 and 2010 were 2.39 and 1.87 [63]. Hence the fertility rates of Indigenous women proved to be substantially higher than the rate observed for the Brazilian population in general, which is below the replacement level, a tendency reflected in the age composition profiles cited previously.

Since the end of the 1990s there has been a notable increase in debates on inequities in health according to colour/race in Brazil, reflected in the production of surveys on differences in mortality rates and other health indicators $[64,65]$. In this area, the main source of data representative at a national level are the registries of the Ministry of Health's Mortality Information System ("Sistema de Informações de Mortalidade", SIM) (Table 1), which since the 1990s has recorded the colour/race of the deceased, with an expansion in the coverage of this data observable over the years [66]. Another important source, one less investigated, in part because it is more recent, is the 2010 Census, which included specific questions on the occurrence of deaths in the households in the year before

\footnotetext{
${ }^{7}$ The total fertility rate (TFR) is the average number of children that would be born or likely to be born to a woman during her life if she were subject to the prevailing rate of age-specific fertility in the population (see http://www.searo.who.int/entity/health_situation_ trends/data/chi/TFR/en/, accessed December 7, 2018).
}

the interview [67]. Making use of both sources, especially the SIM, numerous studies have been published on mortality differentials according to colour/race in Brazil, yet it is notable that often these make no mention of figures for Indigenous groups. Many of the studies of mortality rates according to colour/race do not include Indigenous people, based on the justification that they comprise a small population and that the small number of deaths, compared to the thousands observed for the other colour/race categories, creates statistical difficulties when it comes to calculating the indicators [68].

Emphasizing the need for better knowledge of the mortality levels of Indigenous peoples in Brazil, some recent studies have given special attention to analysing data representative at a national scale, such as the information derived from the SIM and the 2010 Census [69, 70]. For the 2009-2010 period, Caldas et al. [69] reported significantly higher infant mortality rates for the Indigenous population (47.2 deaths per thousand live births according to the SIM data and 27.3 per thousand according to the 2010 Census) when compared to the figures for the Brazilian population overall (16.3 and 15.9 per thousand, respectively) [69]. Based on the data on deaths collected by the 2010 Census, Campos et al. [70] investigated the probability of death in the Indigenous and non-Indigenous population according to gender in three age groups (0-4.9, 5 to 9.9 and 15 to 44.9 years), observing that the figures were always higher for men and for Indigenous people, sometimes as high as double among the first two age groups [70].

In this section we provided a succinct description of a set of aspects relating to the demography of Indigenous peoples in Brazil, based on data from the three most recent national censuses (1991, 2000 and 2010). Since the 1990s, the issue of Indigenous identification has received growing attention from the IBGE, which is reflected in the expansion of the categories of data collected, which more recently have included ethnic 
affiliation and language, among others. We also emphasized that there were variations in the sizes of the Indigenous population between the censuses that cannot be attributed solely to demographic factors, such as inter-relations between birth and death rates. Very possibly aspects linked to classification (such as the inclusion of questions on specific Indigenous ethnic affiliation and Indigenous languages spoken) and to the sociopolitical context (as in 2000, on the occasion of debates concerning the impacts of the 500 years since the arrival of Europeans in the territory that is today Brazil) had an important influence, albeit little is known in terms of its magnitude on the census results. Even in the face of these diverse potential influences, the data from national censuses conducted in Brazil reveal ethnic particularities and also important differences between the Indigenous and nonIndigenous population, which translate into inequities in educational and economic terms and in mortality levels, among others.

\section{Final considerations}

In reflecting critically from a diachronic perspective, we conclude that in Brazil in the 1960s there existed basically a single form of "identifying" Indigenous people in official statistics: the birth and death records that the head of FUNAI's indigenist posts maintained in the communities for which they were responsible. Generally incomplete and insufficiently systemized, these were data on births, deaths and marriages that were not transformed into more comprehensive and reliable demographic profiles of the Indigenous population in Brazil. In the half century since, there has been a profusion of systems for identifying and counting Indigenous people in the country (Table 1). Responding to the fact that the State had failed to count the population systematically over most of the twentieth century, from the 1970s and 1980s non-governmental organisations working in the defence of Indigenous rights and linked to Indigenous movements, began to make efforts to "place Indians on the map of Brazil".

Following the 1988 Federal Constitution, relations between the Brazilian State and Indigenous peoples began to develop on new grounds with the proliferation of public policies, with an emphasis on the areas of education, health, and land rights. It is important to emphasize that the criteria of identification implemented in the various systems are not the same, although as a general pattern they are relatively proximate to the categorization used by the IBGE, which is based on the categories of white, black, yellow, brown and Indigenous, mostly gathered through self-identification, especially in the most recent census rounds (Table 1).

Many challenges remain in relation to the theme of identifying and counting the Indigenous population in official statistics in Brazil. Diverse authors have called attention to the inadequacy of collecting data on Indigenous ethnic affiliation in the context of questions that primarily emphasize notions of colour/race, thus associated with the criteria of physical appearance $[4,16]$. Additionally, it should be pointed out that the methodology of the demographic censuses and other registries of official statistics do not allow individuals to choose more than one category of classification. In Brazil, over the centuries of colonization, there was - in the Brazilian Northeast and diverse other regions - intense miscegenation of Indigenous peoples with populations of African and European origin. For many authors, including those of the present text, while it is recognized that there is no "ideal" system, the categories and forms for recording ethnic-racial affiliation in the official statistics in Brazil are insufficient to capture the existing complexities and nuances.

At the level of international agreements, Brazil has been a signatory to Convention 169 of the International Labour Organization [71] since 2004 and, as a consequence, is committed to making advances in the planning, monitoring and assessment of public policies for Indigenous peoples. In this setting, as well as the complex problems of categorization, multiple challenges exist in relation to the procedures for the collection, analysis and appropriation of data by Indigenous peoples themselves - challenges particularly preeminent at the present moment, during the preparatory process for the 2020 Census. International recommendations, like the Montevideo Consensus on Population and Development and the 2030 Agenda, indicate the need to expand and improve the capture of data according to criteria of ethnicity, recognizing the historical and territorial origins of each ethnic group or community [72]. The immediate challenges for the IBGE include hiring Indigenous census officers or instructors to work in the villages (which did not happen in the 1991, 2000 and 2010 Censuses), making progress in the involvement of Indigenous peoples in the process of designing the research and its results, allowing the disaggregation needed to produce internationally comparable analyses and indicators that are also significant for the Indigenous communities. Another point to emphasise is that, for the 2020 Census, efforts need to be made to capture 
more detailed data on Indigenous people living outside of ILs, in particular those living in urban areas, considering that the urbanization of the Indigenous population is a process that will, on current trends, tend to intensify in the country over the next decades.

Much effort has been made in the production of statistics on Indigenous peoples in Brazil over recent decades, but there is one aspect in particular where the advances have been few: there are practically no Indigenous demographers in the country, with one of the authors of the present study (Colman), as far as we know, being the only Indigenous person with a doctorate in demography in the country. At a moment when the theme of the sovereignty of statistical and demographic data is gaining strength in international debates on the Indigenous issue [73], it is essential that progress is made in Brazil in terms of expanding Indigenous participation at all the different levels involved in the production, systemization, analysis and divulgation of demographic data. This would perhaps be one of the most significant ways of accelerating the reversal of "statistical invisibility", aiming to define more appropriate methodologies for capturing Indigenous data and incorporating Indigenous conceptions of demographic variables, in accordance with their own categories, notions of "living well" and political agendas.

\section{Acknowledgments}

Writing of this paper was supported by grants from the Wellcome Trust (grant 203486/Z/16/Z) and the Brazilian Research Council - CNPq (grant 304358 12014-2). The authors thank Michele Connoly for her careful reading of the manuscript and valuable comments.

\section{References}

[1] Livi-Bacci M. Conquest: the destruction of the American Indios. Cambridge: Polity; 2008.

[2] Clement CR, Denevan WM, Heckenberger MJ, Junqueira AB, Neves EG, Teixeira WG, et al. The domestication of Amazonia before European conquest. Proceedings of the Royal Society B: Biological Sciences. 2015; 282(1812): 20150813.

[3] IBGE. Censo Demográfico 2010: Características gerais dos indígenas - resultados do universo. Rio de Janeiro: IBGE; 2012.

[4] Oliveira JP. Entering and leaving the "melting pot": a history of Brazilian Indians in the national censuses. Journal of Latin American Anthropology. 1999; 4(2): 190-211.
[5] Todorov T. The conquest of America: the question of the other. New York: Harper Perennial; 1992.

[6] Souza Lima AC. Um grande cerco de paz: poder tutelar, indianidade e formação do Estado no Brasil. Petrópolis: Vozes; 1995.

[7] Denevan WM, ed. The native population of the Americas in 1492. Madison: University of Wisconsin Press; 1976.

[8] Souza Lima AC. Indigenous Peoples and the Nation-State in Brazil, XX-XXI Centuries: from tutelage to emancipation. Watson Institute for the International and Public Affairs; 2014 (unpublished paper).

[9] Carneiro da Cunha M. Três peças de circunstância sobre o direito dos índios. In: Cultura com aspas: e outros ensaios. São Paulo: Cosac Naify; 2009. pp. 245-58

[10] Santos RV. Indigenous peoples, bioanthropological research, and ethics in Brazil: issues in participation and consent. In: Ellison GTH, Goodman AH, eds. The nature of difference: science, society, and human biology. Boca Raton, FL: CRC Taylor \& Francis; 2006. pp. 181-202.

[11] Ribeiro D. Convívio e Contaminação - efeitos dissociativos da depopulação provocada por epidemias em grupos indígenas. Sociologia. 1956; 18: 3-50.

[12] Brasil. Estatuto do Índio. Act No.6001, 19.12.1973.

[13] Brasil. Lei de Criação da Fundação Nacional do Índio. Act No.5371, 05.12.1967.

[14] Souza Lima AC, ed. Gestar e gerir: estudos para uma antropologia da administração pública no Brasil. Rio de Janeiro: Relume Dumará: Núcleo de Antropologia da Política; 2002. 314 p.

[15] Brasil. Decreto de Criação do Serviço de Proteção aos Índios e Localização dos Trabalhadores Nacionais. Decree No. 8072, 20.06.1910.

[16] Pagliaro H, Azevedo MM, Santos RV, eds. Demografia dos Povos Indígenas no Brasil. Rio de Janeiro: Editora Fiocruz e Associação Brasileira de Estudos Populacionais; 2005.

[17] Cortina A. Ciudadanos del mundo. Madrid: Allianza Editorial; 1997.

[18] Hooker J. Indigenous inclusion/Black exclusion: Race, ethnicity and multicultural citizenship in Latin America. Journal of Latin American Studies. 2005; 37(2): 285-310.

[19] Maybury-Lewis D, ed. The politics of ethnicity: Indigenous peoples in Latin American states. Cambridge, Mass: Harvard Univ., David Rockefeller Center for Latin American Studies; 2002. 386 p. (David Rockefeller Center series on Latin American studies).

[20] Brasil. Constituição Federal. 1988.

[21] Carneiro da Cunha M, et al. Indigenous peoples boxed in by Brazil's political crisis. Hau: Journal of Ethnographic Theory. 2017; 7(2): 403-426.

[22] Oliveira JP de. Sem a Tutela, uma Nova Moldura de Nação: o pós-constituição de 1988 e os povos indígenas. Brasiliana Journal for Brazilian Studies. 2016; 5(1): 200-29.

[23] Brasil. Conselho de Nacional Proteção aos Índios. Decree No. 1794, 22.11.1939.

[24] Maio MC. O projeto UNESCO e a agenda das ciências sociais no Brasil dos anos 40 e 50. Revista Brasileira de Ciências Sociais. $1999 ;$ 14(41): 141-158.

[25] Brito C. Antropologia de um Jovem Disciplinado: A Trajetória de Darcy Ribeiro no Serviço de Proteção aos Índios (1947-1956). Doctoral Thesis, Casa de Oswaldo Cruz, Fundação Oswaldo Cruz, 2017.

[26] Ribeiro D. Os índios e a civilização - a integração da população indígena no Brasil moderno, $3^{\mathrm{a}}$ ed. Rio de Janeiro: Petrópolis Vozes; 1979. 
[27] Montero P. Selvagens, Civilizados, Autênticos. A produção das diferenças nas etnografias salesianas (1920-1970). São Paulo: Editora da Universidade de São Paulo, 2012.

[28] Rufino M. The Indigenous Missionary Council: A Brazilian experience between culture and Faith. In: Botta S, ed. Manufacturing Others: missions and Indigenous cultures in Latin America. Newcastle upon Tyne: Cambridge Scholars Publishing; 2013.

[29] CIMI - Conselho Indigenista Missionário. Jornal Porantim. 1982.

[30] CEDI - Centro Ecumênico de Documentação e Informação. Povos Indígenas no Brasil 1980. Aconteceu Povos Indígenas no Brasil. 1981; (6): 1-2.

[31] CEDI - Centro Ecumênico de Documentação e Informação. Aconteceu. 1988 June; (457): 16.

[32] Vidal L. Demografia dos grupos étnicos minoritários: índios. Anais do III Encontro Nacional de Estudos Populacionais. Vitória: Associação Brasileira de Estudos Populacionais Abep; 1982.

[33] Wong LLR. Resumo das discussões sobre o tema Etnia e População. Anais do IV Encontro Nacional de Estudos Populacionais. Águas de São Pedro: Associação Brasileira de Estudos Populacionais - Abep; 1984; (3).

[34] Sousa MC, Scatena JHG, Santos RV. O Sistema de Informação da Atenção à Saúde Indígena (SIASI): criação, estrutura e funcionamento. Cadernos de Saúde Pública. 2007; 23(4): 853-61.

[35] INEP - Instituto Nacional de Estudos e Pesquisas Educacionais Anísio Teixeira. Estatísticas sobre educação escolar indígena no Brasil. Brasília: Ministério da Educação; 2007.

[36] Loveman M. National colors: racial classification and the state in Latin America. Oxford: Oxford University Press; 2014.

[37] Nobles M. Shades of citizenship: race and the census in modern politics. Stanford: Stanford University Press; 2000.

[38] Powell B, Silva G. Technocrats compromises: defining race and the struggle for equality in Brazil, 1970-2010. Journal of Latin American Studies. 2018; 50(1): 87-115.

[39] Camargo APR. Mensuração racial e campo estatístico nos censos brasileiros (1872-1940): uma abordagem convergente. Boletim do Museu Paraense Emílio Goeldi. Ciências Humanas. 2009; 4(3): 361-385

[40] Ramos A, ed. Constituições Nacionais e Povos indígenas. Belo Horizonte: Editora UFMG; 2012

[41] Del Popolo F, Schkolnik S. Pueblos indígenas y afrodescendientes em los censos de población y vivienda de América Latina: avances y desafos en el derecho a la información. Notas de Población, Santiago de Chile: Comisión Economica para América Latina y el Caribe - Cepal. 2013; 40(97): 20547.

[42] Wong LLR, Sánchez JA. Esfuerzos para el avance em la investigatión demográfica sobre la población afro-descendiente e indígena em América Latina: rezagados entre los rezagados - una introducción. In: Wong LLR, Sánchez JA, eds. La población afro descendiente e indígena en América Latina. Puntos de reflexión para el debate sobre Cairo +20. Belo Horizonte: ALAP; 2014.

[43] UNITED NATIONS. Economic and Social Council. Permanent forum on Indigenous issues. New York. 16th session Report of the Permanent Forum, New York (May 5); 2017.

[44] Azevedo MM. Censos demográficos e "os índios": dificuldades para reconhecer e contar. In: Ricardo CA, Ricardo F, eds. Povos indígenas do Brasil 1996/2000. São Paulo: Instituto Socioambiental; 2000. pp. 79-83.

[45] Okamoto L, Antunes M, Damasco F. Povos indígenas nas es- tatísticas oficiais: identificação étnica, recomendações internacionais e a experiência brasileira. In: Simões A, Athias L, Botelho L, eds. Panorama nacional e internacional da produção de indicadores sociais: grupos populacionais específicos e uso do tempo. Rio de Janeiro, IBGE; 2018. pp. 224-265.

[46] IBGE. Tendências demográficas: uma análise dos indígenas com base nos resultados da amostra dos censos demográficos 1991 e 2000. Rio de Janeiro: IBGE; 2005.

[47] Pereira NOM. Innovations on measuring the Indigenous population in the 2010 Brazilian Census. Statistical Journal of the IAOS. 2017; 33: 487-494.

[48] de Souza AL, Damasco FS, da Silva Medeiros GBFP, da Silva Barbuda MM. Geoespatial data of Indigenous lands and villages for the demographic Census 2020 in Brazil. Statistical Journal of the IAOS. 2017; 33(3): 661-9.

[49] Santos RV. Prólogo ao dossiê "Demografia dos povos indígenas no Brasil: abordagens socioantropológica. Revista Brasileira de Estudos de População. 2016; 33(2): 231-5.

[50] Azevedo MM. Povos indígenas na América Latina estão em processo de crescimento. In: Ricardo CA, Ricardo F, eds. Povos indígenas do Brasil 2001/2005. São Paulo: Instituto Socioambiental; 2006. pp. 55-58.

[51] Azevedo MM. O censo 2010 e os povos indígenas. In: Ricardo CA, Ricardo F, eds. Povos indígenas do Brasil 2006/2010. São Paulo: Instituto Socioambiental; 2011. pp. 45-48.

[52] Azevedo MM. Os povos indígenas e os censos demográficos no Brasil. In: Berquó E, ed. Demografia na Unicamp: Um O1har sobre a Produção do NEPO. Campinas: Editora da Unicamp; 2017. pp. 551-564.

[53] Azevedo MM, Simoni AT, Cruz AKR. O que o Censo de 2010 pode revelar sobre os povos indígenas no Brasil. In: Ricardo CA, Ricardo F, eds. Povos indígenas do Brasil 20011/2016. São Paulo: Instituto Socioambiental; 2017. pp. 53-57.

[54] Santos RV, Teixeira P. The "Indigenous" category in the 2010 Brazilian National Census. Cadernos de Saúde Pública. 2011; 27(6): 1049.

[55] Ricardo CA, Ricardo F, eds. Povos indígenas do Brasil 2001/2005. São Paulo: Instituto Socioambiental; 2000.

[56] Axelsson P, Skold P, eds. Indigenous Peoples and Demography: The Complex Relation Between Identity and Statistics. New York, Oxford: Berghahn; 2011.

[57] Bastos JL, Santos RV, Cruz OG, Longo LAFB, Silva LO. Sociodemographic characteristics of Indigenous population according to the 2000 and 2010 Brazilian demographic censuses: a comparative approach. Cadernos de Saúde Pública. 2017; 33(Sup 1).

[58] Ricardo CA, Ricardo F, eds. Povos indígenas do Brasil 2011/2015. São Paulo: Instituto Socioambiental; 2017.

[59] Campos MB, Estanislau BR. Demografia dos povos indígenas: os Censos Demográficos como ponto de vista. Revista Brasileira de Estudos de População. 2016; 33(2): 441-49.

[60] Pereira NOM, et al. Demography, territory, and identity of Indigenous peoples in Brazil: The Xavante Indians and the 2000 Brazilian national census. Human Organization. 2009; 68(2): 166-80.

[61] Santos RV, Bastos JL, Cruz OG, Longo LAFB, Flowers NM, Pereira NOM. Parity of Indigenous and non-Indigenous women in Brazil: does the reported number of children born depend upon who answers national census questions? PLoS One. $2015 ; 10$ : 1-15.

[62] Wong LLR. Tendências da fecundidade dos povos indígenas nos Censos Demográficos brasileiros de 1991 a 2010. Revista Brasileira de Estudos de População. 2016; 33(2): 399-421.

[63] Available from: https://sidra.ibge.gov.br/tabela/3727\#resulta 
do, cited 2018 June 11.

[64] Wong LLR, Barros JS, Santos W. Mortalidad infantil e infantojuvenil en Brasil según sexo y color de la piel. In: Wong LLR, Sánchez J, eds. Situación de la Población AfroDescendiente e Indígena en América Latina. Belo Horizonte: Asociación Latinoamericana de Población; 2014. pp. 79-98. (Série e-Investigaciones, 4).

[65] Chor D. Health inequalities in Brazil: race matters. Cadernos de Saúde Pública. 2013; 29(7): 1272-75.

[66] Lima EEC, Queiroz BL. Evolution of the deaths registry system in Brazil: associations with changes in the mortality profile, under-registration of death counts, and ill-defined causes of death. Cadernos de Saúde Pública. 2014; 30(8): 1721-30.

[67] Queiroz BL, Sawyer DOT. O que os dados de mortalidade do Censo de 2010 podem nos dizer? Revista Brasileira de Estudos Populacionais. 2012; 29: 225-38.

[68] Kabad J, Bastos JL, Santos RV. Raça, cor e etnia em estudos epidemiológicos sobre populações brasileiras: revisão sistemática na base PubMed. Physis. 2012; 22(3): 895-918.
[69] Caldas ADR, Santos RV, Borges GM, Valente JG, Portela MC, Marinho GL. Mortalidade infantil segundo cor ou raça com base no Censo Demográfico de 2010 e nos sistemas nacionais de informação em saúde no Brasil. Cadernos de Saúde Pública. 2017; 33(7): 1-13.

[70] Campos MB, Borges GM, Queiroz BL, Santos RV. Diferenciais de mortalidade entre indígenas e não indígenas no Brasil com base no Censo Demográfico de 2010. Cadernos de Saúde Pública. 2017; 33(5): 1-6.

[71] Brasil. Promulga a Convenção n. 169 da OIT sobre povos indígenas e tribais. Decree No. 5051, 19.04.2004.

[72] United Nations. Transforming our World: the 2030 Agenda for Sustainable Development; 2015.

[73] Kukutai T, Taylor J, eds. Indigenous data sovereignty: toward an agenda. Acton: ANU Press; 2016. 